\title{
連続観測記録を用いた大阪湾奧の光環境に関する一考察
}

\author{
The Optical Environment under the Sea in the Head of Osaka Bay Based on a Long-term Field Observation
}

\author{
藤原隆— ${ }^{1}$
}

\section{Ryuichi FUJIWARA}

\begin{abstract}
An optical environment under the sea is important for designing environmental restoration. Irradiance under the sea is affected by SS(Suspended Substance) which is variable spatially and temporally, so it is not so easy to understand the optical environment. Therefore, it is important to investigate actual phenomena in the field. This study describes a decay of incident rays of sunlight with water depth based on the observation in the head of Osaka Bay. The decay of incident rays defined as the absorption coefficient, $k$, was considered. In the result, monthly averaged value of $k$ was between $0.94 \mathrm{~m}^{-1}$ and $1.15 \mathrm{~m}^{-1}$ in the summer and between $0.46 \mathrm{~m}^{-1}$ and $0.59 \mathrm{~m}^{-1}$ in the winter. Moreover, a compensation depth or a compensation point based on $k$ was examined and it suggested that the photon flux density was insufficient for seaweed (or seagrass) on the sea bottom in the head of Osaka Bay.
\end{abstract}

\section{1. はじめに}

海と陸の接点となる沿岸域は, 古来多目的・多機能に 利用され，わが国の産業，経済活動の拠点として，また 生活空間としても重要な位置を占めてきた。その結果, 沿岸域では干拓や埋立に伴い，多くの浅場や干潟が消失 した，それに伴い，閉鎖性の高い内湾域では赤潮が頻発 し，また三大湾では近年青潮が発生するなど社会問題と なった。一方，消滅した干潟を人工的に造成する取り組 みも行われてきている（例えば磯部, 1994 ; 環境庁, 1997)。その場合, 工学的な安定性はもち万んのこと, 生 物が長期的に生息できる環境を作ることが重要である.

生物生息に関しては，食物連鎖の出発点となる一次生 産者は植物（プランクトン，海藻，海草）である。植物 の光合成に光環境は不可欠であるが，水中に入った光は 散乱し減衰する。一般に光合成可能な層は生産層と呼ば れて抢り，その層厚は海水中の懸濁物質の影響を受けて 変化する. 内湾域では, 赤潮, 河川からの濁水流入, ま た工事や船舶による海底付近の攪乱など懸濁物質に影響 する要因が多く，しかもこれらは時空間的に変動する. このような海域で干潟や浅場を新たに造成する場合，海 中の光環境の重要度は高くなると考えられる。

本研究では, 大阪湾最奥部で 4 年間にわたり実施して きた光量子束密度の観測結果から海中における光の減衰 状況を検討・考察し，污濁の進んだ海域における光環境 の実態を明らかにする.

\section{2. 観測方法}

観測は，図-1に示す大阪湾最奥部付近に位置する自社 岸壁を利用して実施した。計測は光量子束密度, 水温,
DOおよび水深について行い，各計測機器は図-2のよう に吊り下げロープを用いて所定の高さに配置した。吊り 下げロープは岸壁上の固定金具に緊結し，シンカーによ

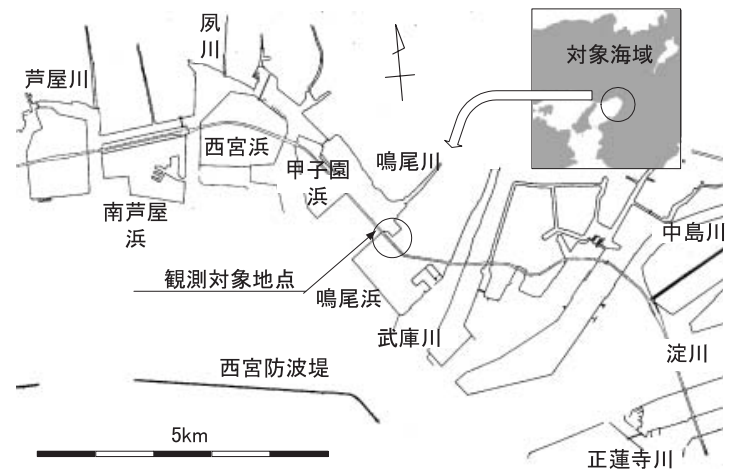

図-1 観測地点

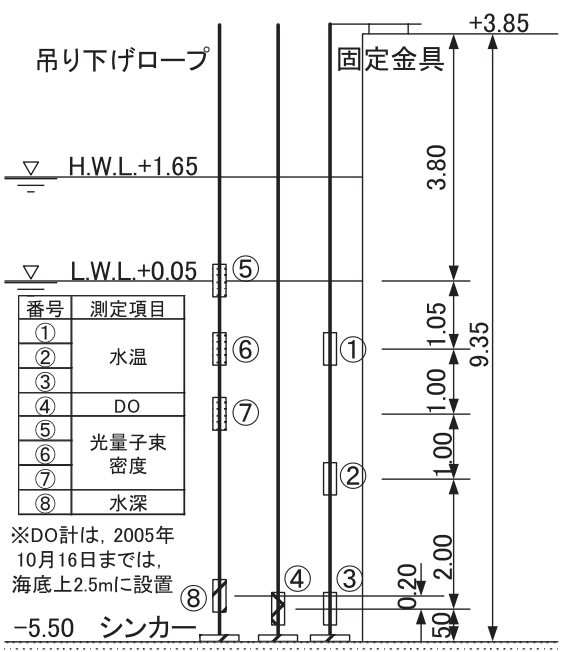

図-2 計測機器の配置 
って緊張を保つょうにした。光量子束密度の測定高は L.W.L.と同じD.L. $+0.05 \mathrm{~m}$ と常時水面下となるD.L.- $1.0 \mathrm{~m}$ およびD.L.-2.0mの3点とした.

観測期間は 2005 年 7 月 12 日から 2009年3月 31 日までの 約 3 年半であり，夏季を 4 回含む. 測定は正時から 10 分 間隔で行い，測定值は内蔵の小型メモリに記録し，定期 的に回収した。計測機器はいずれもJFEアレック社製で, 光量子束密度, 水温㧍よび水深の測定にはMDS-MkVシ リーズ，またDOの測定にはCOMPACT DOWを用いた。 なお, 光量子束密度の測定に関しては, 3 月中旬から9月 までは2-3日に 1 回，それ以外の期間では7日に 1 回の割 合で受光部分を清掃した.

\section{3. 吸光係数の算出方法}

海中の光強度は海中の濁り具合に影響される．海中の 濁り具合を評価する指標としては, 透明度, 濁度, SS, プランクトン細胞数, クロロフィル a 量抒よび吸光係数 (あるいは消散係数) などがある. 本研究では, 水産関 係でよく用いられている海中における光の透過しやすさ の指標である吸光係数 $k$ を用い, 光環境を検討すること とした. $k$ は水深ごとの相対光強度 $Z$ 定める係数で, こ れらの関係はBeer-Lambertの法則から導かれる式（1）で 近似することができる（例えば，能登谷 編著，2003）。

$$
Z=I_{D} / I_{0}=e^{-k D}
$$

ここに, $D$ は水深 $(\mathrm{m}), I_{0}$ および $I_{D}$ はそれぞれ海面お よび水深 $D$ に扔ける光量子束密度 $\left(\mu \mathrm{mol} / \mathrm{m}^{2} / \mathrm{s}\right)$ を示す. このように定義したときの $k$ は $\mathrm{m}^{-1}$ の次元を持つ.

式（1）に観測で得られた 3 点の光量子束密度 $I_{D}$ および それぞれの水深 $D$ を代入し, 最小自乗法によって $I_{0}$ およ びkを算出した。なお，測点が2 点の場合は $I_{0}$ および $k$ は 一意的に決定できる。すなわち2点の組み合わせに対応 する $D$ および $I_{D}$ の組み合わせを $\left(D 1, I_{D 1}\right)$ および $(D 2$, $\left.I_{D 2}\right)$ とすると， $I_{0}$ およ゙ $k$ は式（2）および式（3）より 算出できる。

$$
\begin{aligned}
& I_{0}=10^{B} \\
& k=A \ln 10
\end{aligned}
$$

ここに, $A=\left(\log _{10} I_{D 1}-\log _{10} I_{D 2}\right) /(D 1-D 2)$ および $B=$ $\log _{10} I_{D 1}-A \cdot D 1$ である.

\section{4. 観測結果}

\section{(1) 吸光係数 $k$ および海面における光量子束密度 $I_{0}$ の 推定値}

\section{a) 測点数の違いによる推定値の比較}

観測期間中，潮位がL.W.L.より低下するなどトラブル により2点のデー夕となった場合，式（2）および式（3）
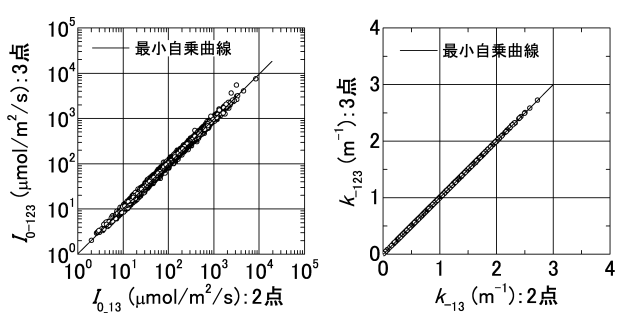

(a) 2 点を D.L.-0.05m およびD.L.-2.0m とした場合
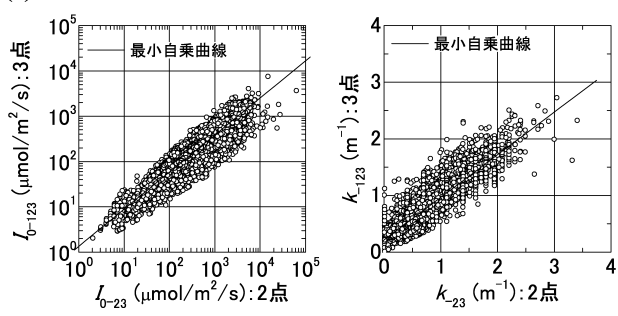

(b) 2 点を D.L.-1.0m およびD.L.-2.0m とした場合 図-3 推定值の比較例（2006年）

を用いて $I_{0}$ および $k$ 算出できるが， 3 点の場合と比べて 推定精度が低下することが懸念された。 そこで 3 点のデ ー夕がある場合のケースを用い，その中の 2 点を用いた 推定值と 3 点のそれを比較し, 推定精度を調べた. 図-3 には，2006年度を例として計測器間の距離が最大および 最小となる組み合わせの場合が示されている， $I_{0}$ および $k$ ともに 3 点による推定值および2点のそれの相関は高い が, 測点距離が小さくなるとばらつきが大きくなり, 2 点による推定值は 3 点のそれより過大となることが分か った．以上より，2点のデー夕を用いて推定する場合， 3 点の推定值との関係を示す最小自乗曲線を用いることで 精度よく補正できると考えられた。

表-1は，図-3に示された最小自乗曲線（線形近似）の

表-1 測定点が 2 点の場合の最小自乗曲線の係数

\begin{tabular}{|c|c|c|c|}
\hline & I & II & III \\
\hline$a$ & 0.004 & 0.076 & 0.202 \\
\hline$b$ & 0.996 & 0.956 & 0.787 \\
\hline$R$ (相関係数) & 0.998 & 0.976 & 0.921 \\
\hline$\sigma \quad$ (標準偏差) & 0.024 & 0.093 & 0.167 \\
\hline \multicolumn{4}{|c|}{ (b) $k$} \\
\hline & I & II & III \\
\hline$a$ & 0.001 & 0.142 & 0.206 \\
\hline$b$ & 1.000 & 0.775 & 0.751 \\
\hline$R$ (相関係数) & 1.000 & 0.874 & 0.871 \\
\hline$\sigma$ （標準偏差） & 0.002 & 0.147 & 0.151 \\
\hline
\end{tabular}
(全期間の平均值)

(a) $I_{0}$

注） I ：D.L.+0.05mと D.L..-2.0mのデータ II : D.L.+0.05mとD.L..-1.0mのデータ III : D.L.-1.0m と D.L..-2.0mのデータ 


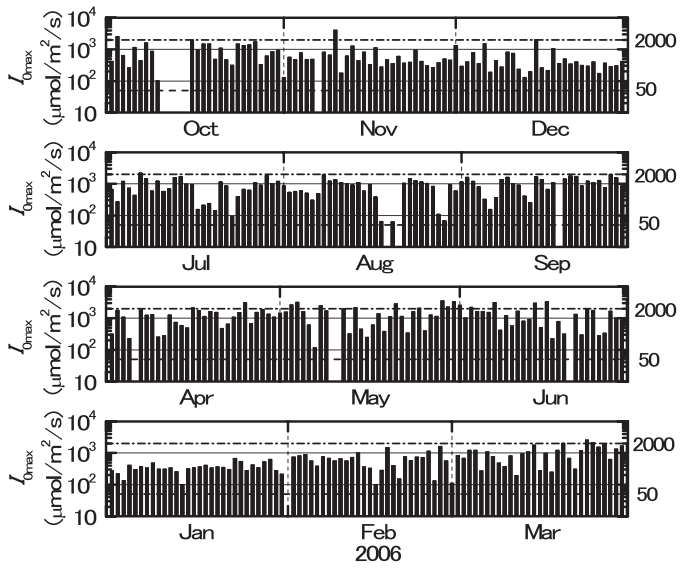

図-4 2006年における $I_{0}$ の日最大值

係数 $a$ (切片),$b$ (勾配) について, 全期間の平均值を 表した結果である。

各ケースの相関係数は 0.871 から $1.000 て ゙ あ り ，$ 相関は 高いと言える。実際に補正を行う場合は, 各年の平均值 を用いて，推定精度の向上を図った。

b）海面における光量子束密度の推定値 $I_{0}$ の妥当性

光量子束密度は, 真夏の直射日光に対しては約 $2000 \mu$ $\mathrm{mol} / \mathrm{m}^{2} / \mathrm{s}$ ，また曇り空では雲量によるが約 $50 \mu \mathrm{mol} / \mathrm{m}^{2} / \mathrm{s}$ で あることが知られている. 海面の光量子束密度 $I_{0}$ の日最大 值とこれらの值を比較することで推定精度を検証した。 図-4は，2006年度における $I_{0}$ の日最大值 $I_{0 \max }$ を例として示 したものである. 図中には, 参考のため $2000 \mu \mathrm{mol} / \mathrm{m}^{2} / \mathrm{s}$ および $50 \mu \mathrm{mol} / \mathrm{m}^{2} / \mathrm{s}$ の值をそれぞれ 1 点鎖線および破線で 表示した。 8 月 12 日から 8 月 20 日の期間は清掃を行うこと ができなかったため，受光部の污濁が進み，8月17日から 8月 20 日にかけて出力が低下した。この期間や欠測期間を 除くと, 推定值はほほ $50 \mu \mathrm{mol} / \mathrm{m}^{2} / \mathrm{s}$ から $2000 \mu \mathrm{mol} / \mathrm{m}^{2} / \mathrm{s}$ の範囲に分布しており，3月から 10 月の期間における $I_{0 \max }$ は最大で約 $2000 \mu \mathrm{mol} / \mathrm{m}^{2} / \mathrm{s}$ となっている. また 1 月, 2 月, 11 月および 12 月の $I_{0 \max }$ は, 3 月から 10 月の期間に比べて 小さくなる傾向が見て取れる. 以上のことから， $I_{0}$ の推定 值は妥当と考えられた. なお, 受光部の污濁は測定精度 を低下させる．清掃の頻度は海域によって異なると考え られるが, 污濁の進んだ海域では今回の頻度，すなわち3 月中旬から9月までは2-3日に1回，それ以外の期間では7 日に 1 回程度が目安になる。

\section{(2) 吸光係数 $k$ の経時変化}

図-5および図-6は, 前図と同じ2006年における吸光係 数 $k$ および表層付近D.L. $-1.0 \mathrm{~m}$ における水温 $T$ の 10 分ごと の経時変化を表している。これらの図から，kの大きさ および変化は表層付近の水温変化, すなわち季節変化に 応じて年間で変動している様子が見て取れる．また，冬
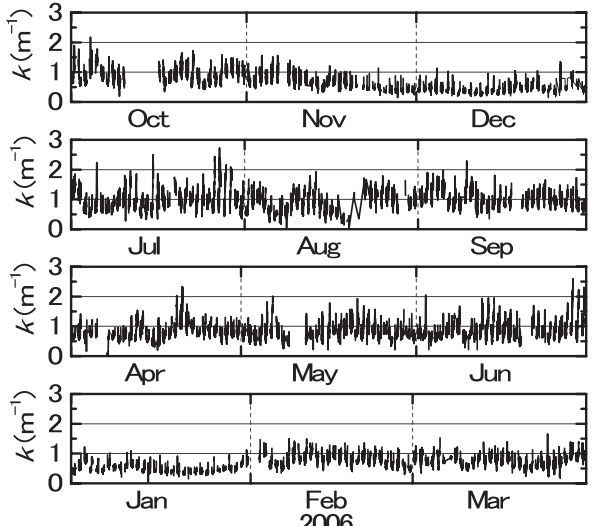

図-5 2006年における $k$ の時間変化
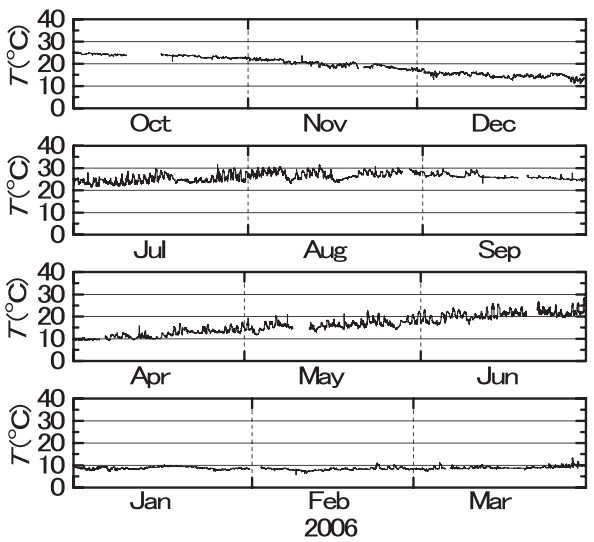

図-6 2006年における表層の水温変化（D.L.-1.0m）
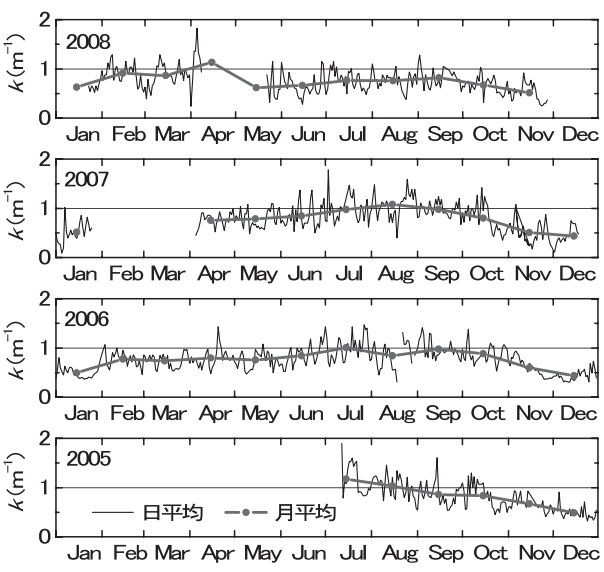

図-7 $k$ の日平均および月平均の経時変化

期（12月，1月）における $k$ の大きさおよび変動幅はその 他の期間に比べて小さく，夏期（6-8月）のそれらは最 も大きい. 短期的な変動特性は藤原（2009）に示される が，後述する日変化によるものである.

図-7には， $k$ の月平均值を観測全期間にわたって示し 
た。 $k$ が最も小さいのは 1 月， 11 月および 12 月で $0.46 \mathrm{~m}^{-1}$ $0.59 \mathrm{~m}^{-1}$ ，逆に大きくなるのは6月-9月で $0.94 \mathrm{~m}^{-1}-1.15 \mathrm{~m}^{-1}$ で あった。一般に， $k$ の大きさは内湾で $0.2 \mathrm{~m}^{-1}-0.5 \mathrm{~m}^{-1}$ 程度, 湾奥のかなり濁った海域で $1.0 \mathrm{~m}^{-1}$ 程度（徳田ら，1995） とされていることと比較すると, 大阪湾奥は年間を通し て濁りの程度が大きい海域と言える.

\section{5. 考察}

\section{（1）吸光係数 $k$ の経時変化に影響する要因}

観測地点は，前出の図-1に示されるように武庫川およ び鳴尾川の河口間に位置する，武庫川からは，出水時に 流出したゴミが漂着するが, 濁水の流入は目視で確認で きるほどではなかった．また鳴尾川ではポンプ排水が行 われており, 流量は小さい。これらのことから, 観測地 点に抢ける濁水の影響は他の影響因子に比べて相対的に 小さいと考えられた。前述のように，kが大きくなる期 間は水温が高く，日射量も大きい。すなわち，水温や日 射が植物プランクトンの増殖に好適となる時期に重なっ ており，これによる水中の懸濁度合いが $k$ の変化に大き く関わっていると推察された。

そこで, $k$ の変動幅が大きい夏期に着目し, 雨量およ び日射との関係を調べた。図-8は2006年7月1日から7月 28 日の 4 週間に㧍ける $k$ の経時変化を示すが，図中には 気象庁のホームページに掲載されている神戸の降水量を 併せて示した。 また, 各図の上部に日降水量を括弧書き した，図-9は同期間の $I_{0}$ を示している，両図を併せて見 ると，降雨があり日射が小さい 7 月 17 日から 7 月 20 日で は， $k$ の日変化は小さく $1.0 \mathrm{~m}^{-1}-1.5 \mathrm{~m}^{-1}$ 程度である。なお, 降水量が最も多かった7月19日の午後に $k$ が大きくなっ ているのは出水の影響と考えるのが妥当である.ただし, 降水量が小さいと $k$ の変化と降雨の関係は明瞭ではなく, 日降水量が $50 \mathrm{~mm}$ を越えるような場合に降雨の影響が現 れる傾向が見られた。一方，降水量のない日に着目する と, $k$ は午前から午後にかけて増加する傾向が見られる. 植物プランクトンに関する測定を行っていないため定性 的な評価に止まるが，日射によって植物プランクトンが 増殖し, 水中懸濁物質が増大することが $k$ の増加に影響 していることが考えられる．また，この期間の日中は南 西風が卓越するので, これらの吹き寄せ効果も要因の一 つとして可能性がある.

ただし，7月22日のように日射が十分にある条件でも $k$ が変化しない場合もあり，さらなる検討が必要である.

\section{（2）日積算光量}

干潟や浅場を造成する場合，造成後に生物が生息でき る環境が必要であり, その場合の食物連鎖の出発点とな る一次生産者は植物（プランクトン，海藻，海草）であ ることは前述した．植物が生長するために必要な一日の
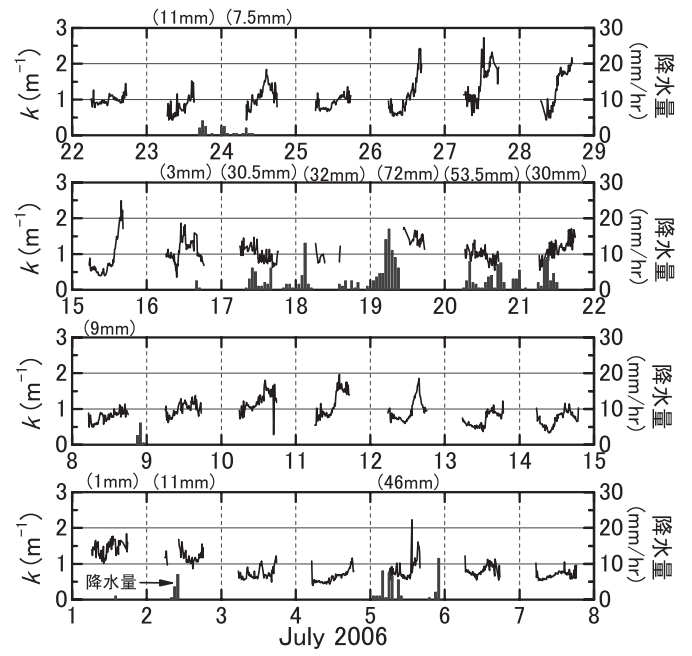

図-8＼cjkstart夏期における $k$ の日変化の例（2006年）
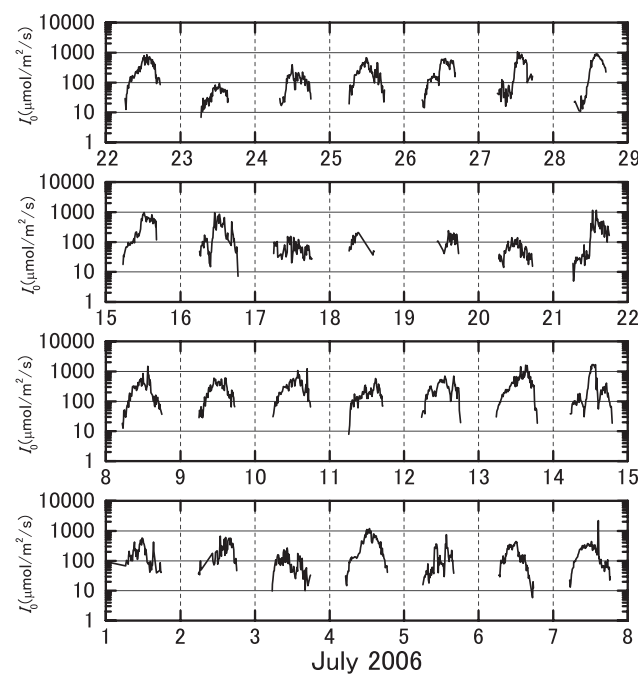

図-92006年7月における $I_{0}$ の経時変化

積算光量である日補償積算量が一つの目安となる. 本研 究では近年その減少が著しく, 干潟や浅場にとって重要 と考えられるアマモを対象とした. アマモの光要求量は 海藻に比べて非常に高いことが知られているが, 日補償 積算量は水温にも依存し, 現地の実測からは春期から夏 期では $3 \mathrm{~mol} / \mathrm{m}^{2}$, また秋期から冬期では $1.5 \mathrm{~mol} / \mathrm{m}^{2}$ 程度 (石川ら，1990；川端ら，1990）とされている. そこで, 式（4）を用いてD.L.-1.0m抽よびD.L.-2.0mにおける日積 算值 $I_{\text {sum }}$ を算出し, 日補償積算量と比較した。

$$
I_{\text {sum }}=\sum_{i=1}^{N} \Delta t \cdot I_{i}
$$

ここに， $\Delta t$ は測定時間間隔 $(=600 \mathrm{~s}), N$ は1日の測定 回数（=144）である. 図-10は, 式（4）により算出し 


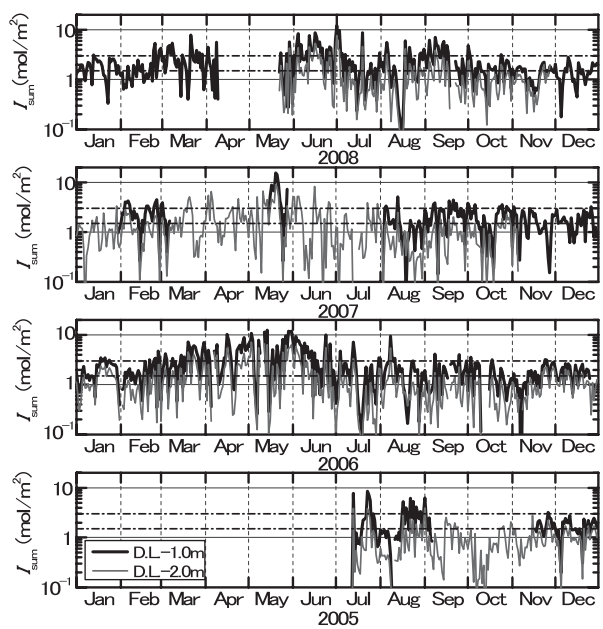

図-10 光量子束密度の日積算值

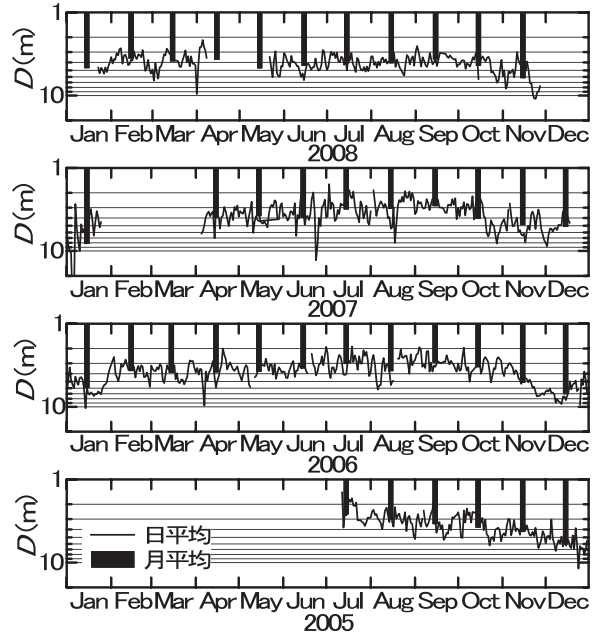

図-11 相対光強度7\% となる海面からの深度の推定值
た $I_{\text {sum }}$ を示した結果である。図中には，上述のアマモの 日補償積算量を一点鎖線で示した。各年とも短期的な変 動を除けば，概ね1月から6月にかけては増加し，その後 は減少に転ずるが，10月から 12 月では長期的な変化は小 さくなるようである，日積算光量の算出値は，D.L.-1.0m ではその季節に対応した日補償積算量とほぼ同等である が，D.L.-2.0mではそれを下回る期間が長くなるようであ る.これらの結果から, 現在の大阪湾奥部においては, アマモの生育できる限界水深は，D.L.-1.0m-D.L.-2.0m程 度であることが推察される。

\section{（3）日補償点}

前節では，日積算量の観点からアマモの生育環境につ いて考察したが，本節では日補償点（限界相対光強度） に着目する．アマモの日補償点は水温によって変わり， 阿部（2005）によると， $7.7 \%\left(10^{\circ} \mathrm{C}\right) ， 6.4 \%\left(15^{\circ} \mathrm{C}\right)$, $7.5 \%\left(20{ }^{\circ} \mathrm{C}\right)$ および $7.9 \%\left(25^{\circ} \mathrm{C}\right)$ と報告されている. そこで，相対光強度が7\%となる海面からの深度を観測 結果から推定し, 図-11に示した. 各年の変化はよく似 ている。そこで月平均值の 4 年間の平均值を算出したと ころ，2月から 10 月の期間では $3.2 \mathrm{~m}-4.1 \mathrm{~m}$, 残りの 1 月, 2 月および11月ではそれらより約 $1 \mathrm{~m}$ 大きい $5.1 \mathrm{~m}-6.2 \mathrm{~m}$ と なった，以上より，日積算光量および日補償点の観点か らは，現在の大阪湾奥でアマモを生息させるような環境 を回復するには，光環境の改善につながる水質の改善が 不可欠と言える。

\section{6. おわりに}

本研究の結果をまとめて以下に示す.

1）約 4 年間の現地観測の結果から吸光係数と海面におけ る光子量束密度の時間変化を明らかにした。

2）吸光係数は季節変化しており，夏期には植物プラン
クトンの増殖によると考えられる日変動が見られた。

3）日積算光量や補償深度の観点から，大阪湾奥の環境 を考察し，長期に生物生息ができる環境とするには光 環境の改善につながる水質の改善が不可欠であること を示した。

4）光量子束密度の測定を行う場合，清掃によって受 光部の污濁を取り除くことが精度確保のため必要で ある。

吸光係数の変化特性については, 植物プランクトン の発生量との関係など，さらなる検討が必要と考えら れる。

謝辞：現地観測時の機器回収・設置には，東洋建設（株） 大阪本店の毛利 順氏（当時, 鳴尾研究所）の助力をい ただいた。ここに記してお礼申し上げる。

\section{参 考 文 献}

磯部雅彦編著（1994）：海岸の環境創造 ウォーターフロント 学入門, 朝倉書店, pp.58-73.

環境庁編（1997）：日本の干潟，藻場，珊瑚礁の現況（第 1 巻 干潟), 291p.

徳田 廣・大野正夫 - 小河久朗（1995）：海藻資源養殖学，水 産養殖資源講座，第 10 巻，緑書房, $354 \mathrm{p}$.

能登谷正浩編著（2003）：藻場の海藻と造成技術，成山道書店， pp.219-222.

阿部真比古（2005）：アマモ群落の構造と環境特性に関する研 究, 三重大学博士論文, pp.48-62.

石川雄介 - 川崎保夫 · 本多正樹 - 丸山康樹 · 五十嵐由雄 （1990）：電源立地点の藻場造成技術の開発 第 9 報, 水中 の光条件に基づくアマモ場造成限界樑度の推定手法, 電 力中央研究所報告 U88010, 23p.

川端豊喜・長谷川恒孝・富田伸明（1990）：柳井湾に抢けるア マモの生長様式とアマモ場造成試験, 沿岸海洋研究ノー 卜, 27, pp.146-155.

藤原隆一（2009）：大阪湾奥における海中の光環境，土木学会 第64回年次学術講演会講演概要集, II -130. 